\section{Bio vs. Mimetics in Bioanalysis: An Editorial}

\author{
Frieder W. Scheller ${ }^{1,2}{ }^{*}$ and Aysu Yarman ${ }^{1,2}$ \\ ${ }^{1}$ Fraunhofer Institute IZI-BB, Am Mühlenberg, Potsdam, Germany \\ ${ }^{2}$ Institute of Biochemistry and Biology, University of Potsdam, Potsdam, Germany
}

*Corresponding author: Frieder WS, Institute of Biochemistry and Biology, University of Potsdam, Karl-Liebknecht-Street, 24-25, 14476 Potsdam, Germany, Tel: +49-331-58187; Fax: +49-331-58187-119; E-mail: fschell@uni-potsdam.de

Rec date: Apr 22, 2015; Acc date: Apr 24, 2015; Pub date: Apr 28, 2015

Copyright: @ 2015 Frieder WS, et al. This is an open-access article distributed under the terms of the Creative Commons Attribution License, which permits unrestricted use, distribution, and reproduction in any medium, provided the original author and source are credited.

\section{Editorial}

Natural evolution has created biopolymers on the basis of amino acids and nucleotides showing high chemical selectivity and catalytic power. Molecular recognition by antibodies and catalytic conversion of the substrate molecules by enzymes take place in so called paratopes or catalytic centres of the macromolecule which comprise typically 10-15 amino acids. The concerted interaction between the reaction partners result in affinities down to nanomolar concentrations for the antigen binding and approaches one million turnovers per second in enzyme-catalyzed reactions.

Nucleic acids bind complimentary single stranded nucleic acids by base pairing (hybridisation) with nanomolar affinities but also interact highly specific with proteins, e.g. transcription factors, and lowmolecular weight molecules and even with ions.

Biomimetic binders and catalysts have been generated using "evolution in the test tube" of non-natural nucleotides or total chemical synthesis of (molecularly imprinted) polymers in order to substitute the biological pendants in bioanalysis.

\section{Molecularly imprinted polymers (MIPs)}

To mimic the active sites of proteins synthetic polymers are imprinted by the analyte during the formation of a polymeric network. In the pre-polymerisation mixture, the target interacts by covalent (pre-organised approach) [1] or non-covalent (self-assembly approach) [2] binding with the chemically active moieties of the functional monomers. This arrangement is fixed in the following polymerization of the functional monomers or the reaction with a cross-linker. After polymerisation the template molecules are removed, providing binding sites ideally complementary in size, shape and functionality to the template thus the template preferential rebinds to the cavity.

Whilst nature has a spectrum of 20 amino acids as building elements of proteins in MIPs only one up to three different functional monomers have been applied. This is a limitation as compared with protein based reagents $[3,4]$. The most common functional monomers applied in thermal or photo polymerisation are methacrylic acid, vinylimidazole, vinylpyridine and their derivatives. In contrast to the three dimensional networks obtained by bulk polymerisation electropolymerisation of pyrrole, phenylenediamine, thiophene, $\mathrm{p}$ aminophenylboronic acid and their derivates in the presence of the target molecule allow the one-step preparation of MIPs for a broad spectrum of analytes $[5,6]$.

Molecularly imprinted polymers have been successfully developed for low molecular weight substances [7]. The application of the simple concept of MIP preparation for complex macromolecular templates like proteins is however still a challenge [8-11]. For effective removal of the target molecule from the polymer and accessibility for rebinding, the binding sites should be located on the surface of the polymers. Therefore, so-called surface imprinting techniques have been developed, where the template is imprinted in ultra-thin polymer films [9,12-14]. Uniform orientation of the templates during polymerization is a prerequisite for homogeneous binding sites $[12,15]$. For this reason the template should be bound during the polymer formation via a site-specific affinity ligand.

MIPs have still found routine application in affinity chromatography and it has been expected that they will substitute antibodies in bioanalysis $[3,8]$. They are especially attractive for toxic targets and for the measurement in organic solvents, i.e. in extracts of environmental samples or foods. In spite of big efforts, the performance of MIPs is still behind that of antibodies. In addition to binding MIPs, catalytically active MIPs have been developed for the application in sensors and syntheses [16-18]. So far, however, the catalytic activity of MIPs have in general been between one percent and one per mill of their biological counterparts. On the other hand MIPs have been prepared as catalysts for reactions where no enzymes are available.

Molecularly imprinted polymers have the potential to replace in future biological recognition elements, especially in affinity chromatography but also biosensors and biochips for the measurement of low molecular weight substances, proteins, viruses and living cells.

\section{References}

1. Wulff G, Sarhan A, Zabrocki K (1973) Enzyme-analogue built polymers and their use for the resolution of racemates. Tetrahedron Lett 14: 4329-4332.

2. Arshady R, Mosbach K (1981) Synthesis of substrate-selective polymers by host-guest polymerization. Makromol Chem 182: 687-692.

3. Haupt K, Mosbach K (2000) Molecularly imprinted polymers and their use in biomimetic sensors. Chem Rev 100: 2495-2504.

4. Whitcombe MJ, Chianella I, Larcombe L, Piletsky SA, Noble J, et al. (2011) The rational development of molecularly imprinted polymer-based sensors for protein detection. Chem Soc Rev 40: 1547-1571.

5. Malitesta C, Mazzotta E, Picca RA, Poma A, Chianella I, et al. (2012) MIP sensors--the electrochemical approach. Anal Bioanal Chem 402: 1827-1846.

6. Sharma PS, Pietrzyk-Le A, D'Souza F, Kutner W (2012) Electrochemically synthesized polymers in molecular imprinting for chemical sensing. Anal Bioanal Chem 402: 3177-3204.

7. Sellergren B, Lepistoe M, Mosbach K (1988) Highly enantioselective and substrate-selective polymers obtained by molecular imprinting utilizing noncovalent interactions. NMR and chromatographic studies on the nature of recognition. J Am Chem Soc 110: 5853-5860. 
Citation: Scheller FW, Yarman A (2015) Bio vs. Mimetics in Bioanalysis: An Editorial. Biochem Anal Biochem 4: e154. doi: 10.4172/2161-1009.1000e154

Page 2 of 2

8. Hayden O, Lieberzeit PA, Blaas D, Dickert FL (2006) Artificial Antibodies for Bioanalyte Detection-Sensing Viruses and Proteins. Adv. Funct. Mater 16: $1269-1278$.

9. Rachkov A, Minoura N (2001) Towards molecularly imprinted polymers selective to peptides and proteins. The epitope approach. Biochimica et Biophysica Acta (BBA) - Protein Structure and Molecular Enzymology 1544: 255-266.

10. Ertürk G, Uzun L, Tümer MA, Say R, Denizli A (2011) Fab fragments imprinted SPR biosensor for real-time human immunoglobulin $G$ detection. Biosens Bioelectron 28: 97-104.

11. Kryscio DR, Peppas NA (2012) Critical review and perspective of macromolecularly imprinted polymers. Acta Biomater 8: 461-473.

12. Nishino H, Huang CS, Shea KJ (2006) Selective protein capture by epitope imprinting. Angew Chem Int Ed Engl 45: 2392-2396.

13. Lautner G, Kaev J, Reut J, Öpik A, Rappich J (2011) Selective Artificial Receptors Based on Micropatterned Surface-Imprinted Polymers for
Label-Free Detection of Proteins by SPR Imaging. Advanced Functional Materials 21: 591-597.

14. Dechtrirat D, Jetzschmann KJ, Stöcklein WFM, Scheller FW (2012) Protein Rebinding to a Surface-Confined Imprint. Adv. Funct. Mater 22: 5231-5237.

15. Tai DF, Ho YF, Wu CH, Lin TC, Lu KH, et al. (2011) Artificial-epitope mapping for CK-MB assay. Analyst 136: 2230-2233.

16. Wulff G (2002) Enzyme-like catalysis by molecularly imprinted polymers. Chem Rev 102: 1-27.

17. Lettau K, Warsinke A, Katterle M, Danielsson B, Scheller FW (2006) A bifunctional molecularly imprinted polymer (MIP): analysis of binding and catalysis by a thermistor. Angew Chem Int Ed Engl 45: 6986-6990.

18. Yarman A, Scheller FW (2013) Coupling biocatalysis with molecular imprinting in a biomimetic sensor. Angew Chem Int Ed Engl 52: 11521-11525. 